\title{
Universal Exchange and Trade Rates
}

\section{Israel O.E Idewele}

Department of Banking and Finance, Veritas University, Bwari, Abuja

idewelei@gmail.com

\section{Abstract}

This paper dissects the connection between universal exchange and conversion scale levels with regards to the worldwide money related emergency $(G F C)$ and the ascent of worldwide and provincial esteem chains (GVCs). Utilizing two-sided information for 72 economies over the 2001-2015 period, we locate a positive connection between the genuine conversion standard and fare volume pre-GFC; however this relationship for the most part vanishes post-GFC. We additionally analyze the effect of extending GVCs on exchange and on the conversion scale exchange connect channel. The examination affirms that expanded investment in GVCs brings down the effect of the conversion standard on fares, and could be a contributing element to debilitating connections between trade rates and exchange. Ultimately, other auxiliary variables, for example, import organization and load of transient outside obligation of exporters and merchants, appear to significantly affect exchange execution yet less effect on the conversion scale exchange connect channel post-GFC.
Keywords

trade volume; real; exchange rate; gravity, model; global value chains

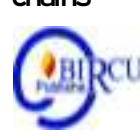

\section{Introduction}

In the previous 15 years, worldwide exchange has changed colossally. Exchange development has hindered essentially since the worldwide money related emergency (GFC), and with the exception of a speedy bounce back after the emergency, it just recouped gradually a short time later. A few examinations explore its fundamental drivers and whether patterned or basic variables underlie the marvel. Specifically, the effect of trade rates on exchange and the effectiveness of swapping scale arrangements as a device in aligning a nation's outside position and local financial strength has been a mainstream subject in the writing. The commitment of this paper to the current writing is to look at the connection between the dimension of genuine conversion scale and exchange volume the nearness of auxiliary changes in the exchange development design pre-and post-GFC utilizing a gravity model. What's more, the paper examines the potential factors that can clarify the debilitating connection between swapping scale and exchange, for example, worldwide and territorial esteem (GVCs), changing import item structure and arrangement, and transient outside obligation introduction of nations.

Technical analysis is an important measure for studying and observing based on the company's financial performance, demand and supply, interest rates, risk levels, inflation rates, government policies, political conditions and security of a country. (Janice et.al. 2020:494), Decision making can be interpreted as a systematic approach to the nature of the alternative faced and take action which according to the calculation is the most appropriate action (Hasan, 2002). This decision making is a very important first step and even occupies a key position in achieving organizational performance (Wu et al., 2017). The inability of organizations to make the right decisions at the right time resulted in 
Konfrontasi Journal: Culture, Economy and Social Changes, 7 (2) June 2020, 158-167

ISSN: 1410-881X (Print), 2716-2095 (Online)

Israel O.E Idewele: Universal Exchange and Trade Rates

DOI: https://doi.org/10.33258/konfrontasi2.v7i2.109

http://www.konfrontasi.net/index.php/konfrontasi2

several organizations finally declaring bankruptcy and closing down (Warsani 2020:599). Successful entrepreneurs possess behavioral quality consistent with the dimensions of the college students' daily behavior scale. (Li Bing-quan, et.al. 2020)

While much writing demonstrates the noteworthy effect of the conversion scale level and its instability on exchange, heap look into likewise indicates uncertain and irrational outcomes (Aristeriou, Masatci, and Pilbeam, 2016; Dell'Ariccia, 1999; Mukherjee and Pozo, 2011; Rose, 2000). Bacchetta and van Wincoop (2000) dissect the relationship and find that the stuns causing changes in the swapping scale can prompt changes in other macroeconomic factors, which could offset the effect of conversion standard on exchange, while Koren and Szeidl (2003) take a gander at the covariance in the development of trade rates and key macroeconomic factors and find that what is important isn't conversion scale unpredictability yet rather how it amplifies or directs the dangers looked by firms or con-sumers. Aristotelous (2001) and IMF (2004) utilize a gravity condition determination to evaluate the effect of swapping scale instability on exchange and their observational discoveries recommend that conversion scale unpredictability has no effect on fare volumes.

\section{Review of Literature}

One analysis of observational work utilizing conversion scale unpredictability is that instability itself is anything but a basic issue for universal exchange, in light of the fact that there are money related instruments that organizations can use to support against this hazard (Ethier, 1973); and the nearness of fixed expenses in sending out (Franke, 1991; Krugman, 1989) undermines the importance of the unpredictability of trade rates on exchange. UNCTAD (2013) explores this issue by looking at two models - utilizing conversion standard unpredictability and swapping scale misalignment (i.e., the difference between the watched genuine effective conversion scale (REER) and that rate balanced for the BalassaSamuelson effect). Utilizing straightforward board investigation, their outcomes affirm prior discoveries of no effect of conversion scale unpredictability on exchange however they do locate a critical effect of money misalignment. They find that undervaluation results in advancement of fares and confinement of imports. Huchet-Bourdon and Korinek (2011) find that trades are touchier to changes in RER levels than their instability and the effect is increasingly articulated in the farming division sends out.

Occasion (2008) audits the job of focused monetary standards in the financial development of East and Southeast Asian economies. Marquez and Schindler (2006) researches the genuine conversion scale effects on the People's Republic of China's (PRC) share in world exchange, and the outcomes recommend that energy about the renminbi brings down the PRC's offer in total fares and builds its offer in total imports with littler effect. Appuhamilage and Senanayake (2010) contemplate the respective fares of Sri Lanka and the PRC and reason that the devaluation of Sri Lankan rupee against the Chinese renminbi has a critical positive effect on fares of Sri Lanka to the PRC, while the deterioration has negative effects on its imports from the PRC. Baek (2012) contemplates fares and imports of 71 items between the US and the Republic of Korea and reasons that fares and imports of the Republic of Korea from the US are affected by conversion scale levels. Hooy, Law, and Chan (2015) likewise utilizes division level information to survey the effect of the Chinese renminbi on the fares of the ASEAN as real exchange accomplices the worldwide supply chains of the PRC and the outcomes point to the critical positive effect of genuine swapping scale deterioration on fares of high-innovation and medium-innovation last and middle merchandise.

Thorbecke (2006) finds that conversion standard thankfulness in created Asia - because of the deterioration of the US dollar - could upset complimentary exchange association with 
creating economies Asia, particularly in innovation serious merchandise. Thorbecke and Kato (2011) investigate a specific section of fares (i.e., utilization products) and their evaluations propose that a valuation for the Japanese yen prompts a decrease of utilization fares of Japan.

Another strand of research considers the connection between swapping scale level and global exchange volume, in the wake of taking out the unstable value factor. Since the GFC, scholastic and strategy discusses have resuscitated and moved from swapping scale instability (ostensible or genuine) to the genuine conversion standard dimension, with worries about worldwide outer lopsided characteristics, moderate recuperation, and the effect of supported cash misalignments (WTO, 2011). Devaluation would regularly expand a nation's fares and decrease imports because of changes as far as exchange and the effect of value versatility of interest. Be that as it may, new examples of universal exchange, including the development of GVC, for instance, render the effect of trade rates on exchange more unpredictable than previously. Discoveries in Ollivaud, Rusticelli, and Schwellnus (2015) and Ahmed, Appendido, and Ruta (2015a) propose that the ascent of GVCs debilitated the effect of trade rates on exchange; and the versatility of assembling send out volume to the genuine effective swapping scale has diminished after some time (Ahmed, Appendido, and Ruta, 2015b). Yet, writing on this issue is still on its outset.

\section{Research Methods}

The estimation after effects of the dynamic gravity model utilizing board relapse over 2001- 2015 are introduced in Table 1 and demonstrate that the impact of normal gravity factors, for example, separate, pioneer relationship, regular language, and geological contiguity on fare volume, is critical and has the normal bearing. Table 1 demonstrates the powerful effect of lnRERijt on fares volume. The coeffcient of lnRERijt is sure and huge at the $1 \%$ level. This proposes the flimsier the exporter's money, the bigger the fare volume to its exchanging accomplices, with the end goal that a $1 \%$ devaluation of an

Table 1. Dynamic gravity model estimation results, 2001-2015

\begin{tabular}{|c|c|c|c|}
\hline & $(1)$ & (2) & (3) \\
\hline \multirow[t]{2}{*}{ Log of exporter's GDP } & $0.430^{\star \star \star}$ & $0.240^{\star \star}$ & 0.130 \\
\hline & -0.113 & -0.109 & -0.111 \\
\hline \multirow[t]{2}{*}{ Log of Distance } & $-1.536^{\star \star \star}$ & $-1.602^{\star \star \star}$ & $-1.628^{\star \star *}$ \\
\hline & $(0.0367)$ & $(0.0339)$ & $(0.0335)$ \\
\hline Colonial relationship dummy & $0.257^{*}$ & 0.208 & $0.249^{*}$ \\
\hline \multirow{2}{*}{ Common language dummy } & $\begin{array}{l}(0.149) \\
0.779^{* \star *}\end{array}$ & $\begin{array}{r}(0.164) \\
0.690^{* * *}\end{array}$ & $\begin{array}{r}(0.151) \\
0.680^{* \star *}\end{array}$ \\
\hline & $(0.0853)$ & $(0.0771)$ & $(0.0762)$ \\
\hline Contiguity & $\begin{array}{l}0.420^{\star *} \\
(0.178)\end{array}$ & $\begin{array}{l}0.420^{* *} \\
(0.184)\end{array}$ & $\begin{array}{r}0.452^{* *} \\
(0.178)\end{array}$ \\
\hline Log of bilateral RER & $\begin{array}{l}0.353^{\star * *} \\
(0.0601)\end{array}$ & & \\
\hline \multicolumn{2}{|l|}{ Log of 1 period lag bilateral RER } & $\begin{array}{l}0.161^{* \star *} \\
(0.0514)\end{array}$ & \\
\hline \multicolumn{2}{|l|}{ Log of 2 period lag bilateral RER } & & $\begin{array}{r}0.0745 \\
(0.0461)\end{array}$ \\
\hline Constant & $\begin{array}{r}16.95^{\star \star \star} \\
(3.033)\end{array}$ & $\begin{array}{r}22.50^{\star \star *} \\
(2.922)\end{array}$ & $\begin{array}{r}24.67^{* * *} \\
(2.976)\end{array}$ \\
\hline Observations & 56,815 & 55,827 & 54,982 \\
\hline Number of country-pairs & 4,418 & 5,509 & 5,706 \\
\hline R-squared & 0.78 & 0.78 & 0.78 \\
\hline
\end{tabular}

Note: Importer time-varying fixed effects and exporter fixed effects are estimated, but not shown for brevity.

$\mathrm{p}<0: 10 ; \mathrm{p}<0: 05 ; \mathrm{p}<0: 01$ Robust standard errors are in parentheses. 
Exporter's RER, by and large, prompts a $0.35 \%$ expansion in fare volume for that year. The slack variable lnRERijt-1 has a lower, yet at the same time positive and noteworthy effect on fare volume contrasted with the dimension RER. The coefficient of lnRERijt-1 is

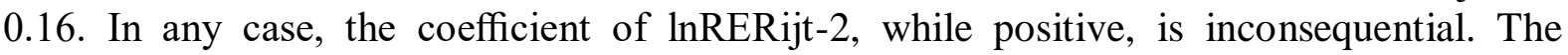
incorporation of time-fluctuating merchant fixed effects in the model enables us to represent the in secret time-changing attributes of the shippers which could impact exchange, generally not caught by GDP and factors as in the fixed effects model.

Table 2, presents' estimation consequences of the dynamic gravity model however with disaggre-gated timespans to represent watched basic difference in exchange designs somewhere in the range of 2001 and 2015. For this reason, this paper thinks about three periods - 2003- 2006 (pre-GFC), 2007- 2010 (GFC), and 2012- 2015 (post-GFC). The extent of the RER coefficient recoils from lnRERijt to lnRERijt-1 and to lnRERijt-2. It can likewise be seen in the outcomes that the greatness of RER's coefficient is bigger for the preGFC period than amid the post-GFC period, while it is intensified amid the emergency. The swapping scale effect on fare volume was essentially hosed after the emergency time frame. Ultimately, note that the coefficient of lnRERijt-2 was even negative in the post-GFC period, when contrasted with the GFC time frame, and both are factually critical. To outline, the coefficient of lnRERijt is 1.05 in the GFC time frame and it is -0.27 in the post-GFC period, however factually immaterial, while all things considered, for the whole time frame, it is 0.35. The positive effect is for the most part determined by the emergency time frame and the extent has been less post-emergency. A $1 \%$ deterioration of exporter's money prompts $1.05 \%$ expansion in fares volume in 2007-2010, yet the effect is effectively nil in 2012-2015.

Table 2. Dynamic gravity model estimation results, 2003-2006 vs. 2007-2010 vs. 2012-2015

\begin{tabular}{|c|c|c|c|c|c|c|c|c|c|}
\hline & Pre-GFC & GFC & Post-GFC & Pre-GFC & GFC & Post-GFC & Pre-GFC & GFC & Post-GFC \\
\hline \multicolumn{10}{|l|}{ Log of } \\
\hline GDP & $\begin{array}{c}-0.147 \\
(0.446)\end{array}$ & $\begin{array}{c}0.135 \\
(0.249)\end{array}$ & $\begin{array}{l}2.149^{* \star *} \\
(0.463)\end{array}$ & $\begin{array}{l}-0.149 \\
(0.442)\end{array}$ & $\begin{array}{c}-0.0800 \\
(0.237)\end{array}$ & $\begin{array}{l}2.010^{* * *} \\
(0.495)\end{array}$ & $\begin{array}{c}-0.112 \\
(0.440)\end{array}$ & $\begin{array}{r}0 \\
(0.230)\end{array}$ & $\begin{array}{l}1.838^{* * *} \\
(0.502)\end{array}$ \\
\hline Log of & & & & & & & & & \\
\hline distance & $\begin{array}{c}-1.527^{* * *} \\
(0.0403)\end{array}$ & $\begin{array}{l}-1.552^{* * *} \\
(0.0411)\end{array}$ & $\begin{array}{l}-1.448^{* * *} \\
(0.0428)\end{array}$ & $\begin{array}{c}-1.513^{\star * *} \\
(0.0401)\end{array}$ & $\begin{array}{l}-1.550^{\star * *} \\
(0.0410)\end{array}$ & $\begin{array}{l}-1.452^{\star * *} \\
(0.0429)\end{array}$ & $\begin{array}{c}-1.512^{* * *} \\
(0.0401)\end{array}$ & $\begin{array}{l}-1.550^{* * *} \\
(0.0409)\end{array}$ & $\begin{array}{l}-1.478^{* * *} \\
(0.0421)\end{array}$ \\
\hline \multicolumn{10}{|l|}{$\begin{array}{l}\text { Colonial } \\
\text { relationship }\end{array}$} \\
\hline dummy & $\begin{array}{c}0.300^{*} \\
(0.165)\end{array}$ & $\begin{array}{c}0.208 \\
(0.161)\end{array}$ & $\begin{array}{l}0.0905 \\
(0.170)\end{array}$ & $\begin{array}{c}0.285^{\star} \\
(0.164)\end{array}$ & $\begin{array}{c}0.182 \\
(0.168)\end{array}$ & $\begin{array}{l}0.0923 \\
(0.170)\end{array}$ & $\begin{array}{c}0.283^{*} \\
(0.164)\end{array}$ & $\begin{array}{c}0.182 \\
(0.169)\end{array}$ & $\begin{array}{c}0.151 \\
(0.165)\end{array}$ \\
\hline \multicolumn{10}{|l|}{$\begin{array}{l}\text { Common } \\
\text { language }\end{array}$} \\
\hline dummy & $\begin{array}{l}0.770^{\star * *} \\
(0.0963)\end{array}$ & $\begin{array}{l}0.853^{* * *} \\
(0.0978)\end{array}$ & $\begin{array}{l}0.778^{\star \star \star} \\
(0.100)\end{array}$ & $\begin{array}{l}0.835^{\star * *} \\
(0.0957)\end{array}$ & $\begin{array}{l}0.854^{\star * *} \\
(0.0987)\end{array}$ & $\begin{array}{l}0.780^{\star * *} \\
(0.100)\end{array}$ & $\begin{array}{l}0.840 * * * \\
(0.0958)\end{array}$ & $\begin{array}{l}0.849^{* * *} \\
(0.0984)\end{array}$ & $\begin{array}{l}0.749^{* * *} \\
(0.0996)\end{array}$ \\
\hline Contiguity & $\begin{array}{l}0.522^{* * \star} \\
(0.187)\end{array}$ & $\begin{array}{l}0.379^{* *} \\
(0.192)\end{array}$ & $\begin{array}{c}0.349^{*} \\
(0.201)\end{array}$ & $\begin{array}{l}0.528^{* * *} \\
(0.186)\end{array}$ & $\begin{array}{l}0.394^{\star \star} \\
(0.191)\end{array}$ & $\begin{array}{c}0.343^{*} \\
(0.202)\end{array}$ & $\begin{array}{l}0.528^{\star * *} \\
(0.186)\end{array}$ & $\begin{array}{l}0.397^{\star *} \\
(0.190)\end{array}$ & $\begin{array}{c}0.287 \\
(0.202)\end{array}$ \\
\hline $\begin{array}{l}\text { Log of bilateral } \\
\text { RER }\end{array}$ & $\begin{array}{r}0.0404 \\
(0.213)\end{array}$ & $\begin{array}{l}1.053^{* * *} \\
(0.184)\end{array}$ & $\begin{array}{l}-0.277 \\
(0.211)\end{array}$ & & & & & & \\
\hline $\begin{array}{l}\text { Log of } 1 \text { period } \\
\text { lag bilateral } \\
\text { RER }\end{array}$ & & & & $\begin{array}{l}-0.221 \\
(0.145)\end{array}$ & $\begin{array}{r}0.151^{* *} \\
(0.0615)\end{array}$ & $\begin{array}{l}-0.444 \\
(0.327)\end{array}$ & & & \\
\hline $\begin{array}{l}\text { Log of } 2 \text { period } \\
\text { lag bilateral }\end{array}$ & & & & & & & & & \\
\hline RER & & & & & & & $\begin{array}{c}-0.137^{* *} \\
(0.0644)\end{array}$ & $\begin{array}{r}0.115^{\star *} \\
(0.0470)\end{array}$ & $\begin{array}{l}-0.822^{* *} \\
(0.383)\end{array}$ \\
\hline Constant & $\begin{array}{l}30.81^{* * *} \\
(11.92)\end{array}$ & $\begin{array}{l}20.81^{* * *} \\
(6.868)\end{array}$ & & $\begin{array}{l}31.70^{* * *} \\
(11.81)\end{array}$ & $\begin{array}{l}31.69^{* * *} \\
(6.329)\end{array}$ & & $\begin{array}{l}31.10^{\star * \star} \\
(11.71)\end{array}$ & & $\begin{array}{c}-20.37 \\
(13.47)\end{array}$ \\
\hline $\begin{array}{l}\text { Observations } \\
\text { Number of }\end{array}$ & 15,229 & 14,662 & 12,137 & 15,205 & 14,907 & 12,346 & 15,260 & 14,971 & 12,567 \\
\hline $\begin{array}{l}\text { country-pairs } \\
\text { R-squared }\end{array}$ & $\begin{array}{l}4,079 \\
079\end{array}$ & $\begin{array}{l}3,985 \\
079\end{array}$ & $\begin{array}{l}3,311 \\
079\end{array}$ & 3,965 & 3,988 & 3,313 & 3,965 & 4,028 & 3,542 \\
\hline
\end{tabular}


Pre-worldwide money related emergency covers 2003- 2006, worldwide monetary emergency covers 2007-2010, and post-worldwide budgetary emergency covers 20122015. Shipper time-changing fixed effects, and exporte fixed effects are evaluated, yet not appeared for brevity. $\mathrm{p}<0: 10 ; \quad \mathrm{p}<0: 05 ; \quad \mathrm{p}<0: 01$ Robust standard mistakes are in brackets.

The relapse aftereffects of the fixed effects model which includes the GDP of the bringing in nations, and exporter, shipper and time fixed effects are commonly reliable with the outcomes examined above for the dynamic gravity model.2 Alternative details of the models utilizing send out costs rather than maker costs - as a vigor check - affirms prior discoveries on the more fragile effect of conversion scale on exchange among pre-and postGFC period.

\subsection{Impact of Global Value Chains}

One potential reason for the stifled effect of trade rates on exchange, post-GFC, could be an extending of GVCs. As we have appeared in the Tables 1 and 2, a deterioration of exporter's RER results in higher fares. In any case, this relationship could be hosed if the traded merchandise implants an extensive bit of imported intermediates, as these are affected by the deterioration, darkening the net effect of exporter's money devaluation. To test this, the dynamic gravity model was altered to represent the GVC share in fares. Given the information accessibility of GVC markers, this area utilizes the normal fare volume, GDP, and conversion scale factors throughout the years 2001-2003, 2006-2008, 2009-2011, and 2012- 2014. In particular, the GVC pointer utilized was the DVA share out of gross twosided sends out for 2000, 2005, 2008, and 2011. This methodology likewise evaluates the conceivable relentless effect of GVC investment spread over different years. A littler offer of DVA out of gross fares implies more investment in GVC (i.e., extending GVCs). 3 The normal indication of the association between DVA offer and swapping scale is negative, with the end goal that when an economy has lower DVA share - it takes an interest more in GVCs - the effect of conversion scale on fares will be less.

Table 3 demonstrates the offer of DVA in gross fares from 2000 to 2015. In 2000, DVA represented $74 \%$ of gross fares, at that point tumbled to $72.2 \%$ in 2005 , sliding further to $70.2 \%$ in 2008 . The DVA share expanded in 2011 to $72.2 \%$, and to $79.4 \%$ in 2015 . As examined before, higher DVA share when all is said in done compares to less cooperation in GVCs. Table 4 presents outline results under the dynamic gravity model with time-shifting merchant fixed-effects. Generally speaking, a bigger DVA share prompts less reciprocal fares. This shows extending GVCs prompts bigger fares, affirming the theory that fast extension of GVCs has added to global exchange development. The effect of normal genuine swapping scale, lnRERijt on fares winds up negative in the wake of considering the GVC sway, while lnRERijt-1 still has positive coefficient. The interac-tion between DVA offer and lnRERijt has a negative coefficient of -0.085 and its greatness suggests that developing GVC, as spoken to by bringing down the DVA share

Table 3. Domestic value added (\% of gross exports)

\begin{tabular}{lccccc} 
& 2000 & 2005 & 2008 & 2011 & 2015 \\
\hline $\begin{array}{l}\text { DVA (\% of gross } \\
\text { exports) }\end{array}$ & 74.00 & 72.18 & 70.22 & 72.19 & 79.38 \\
\hline
\end{tabular}

Note: $\overline{\mathrm{DVA}}=$ domestic value added. Source: Authors' computation using ADB MultiRegional Input Output Tables, and methodology from Wang et al. (2014). 
Table 4. Global value chain effects

\begin{tabular}{lcr} 
& & Dynamic gravity model \\
\cline { 2 - 3 } DVA share & $(1)$ & $(2)$ \\
Log of bilateral RER & $-1.237^{* * *}$ & $(0.191)$ \\
Log of 1 period lag bilateral RER & $-0.206^{* * *}$ & $(0.210)$ \\
Log of bilateral RER $\times$ DVA share & $(0.0567)$ & $0.0694^{* * *}$ \\
Log of 1 period lag bilateral RER $\times$ DVA share & & $(0.0376)$ \\
& & \\
& & $-0.0854^{*}$ \\
\end{tabular}

Note: $\mathrm{p}<0: 10 ; \quad \mathrm{p}<0: 05 ; \quad \mathrm{p}<0: 01$ Robust standard errors are in parentheses.

By $1 \%$, diminishes the conversion scale sway on fares by $0.09 \%$. At the point when the association with lnRERijt-1 is considered, the effect increases: $0.11 \%$. These propose that the developing GVCs could have hosed the conventional instrument of swapping scale levels affecting exchange. Be that as it may, these outcomes can't separate GVC as the main factor that may have actuated the debilitating effect of conversion standard on exchange; they just show that it could be one of the auxiliary variables.

\subsection{Impact of Composition in Imported Good}

Another conceivable basic factor that can impact the relationship of trade rates and exchange is its organization, reflected in the proportion of essential to handled great of the imports of nation $\mathrm{j}$ from exporter nation I at time t. Increasingly essential products exchange contrasted with prepared merchandise could prompt a higher effect of the swapping scale and the move to made products imports could add to the decrease in the effect of the conversion standard on exchange (Campa and Goldberg, 2005). For instance, economies which are sending out item merchandise are progressively delicate to conversion standard changes. Be that as it may, if the import blend is increasingly one-sided to handled products, which are probably going to have imported substance, it could likewise have an offsetting effect on the effect of cash deterioration on fares volume. Finally, to control at the cost effect, value deflators for essential merchandise and handled (or made) products were utilized.

Table 5 demonstrates that the deterioration of the exporter's money results in higher fare volume, despite the fact that the effect ends up negative post-GFC. The relapse results likewise show that InPrimijt for the estimation time frame 2005- 2015 negatively affects trades volume. This implies for a given nation pair I and j, if the proportion of essential to prepared products is higher, there is less fare volume between nation I and $\mathrm{j}$. The connection term of lnPrimijt with lnRERijt has a negative and noteworthy coeffi-cient of -0.004 and -0.005 amid the pre-GFC and GFC period. These outcomes show that higher essential products sends out with respect to handled merchandise trades prompts a littler effect of trade rates on fares volume, of which the effect has progressed toward becoming dam-pened postGFC. To control for conceivable endogeneity, the model was likewise evaluated with the slacked RER. The outcomes are predictable with the model with level RER. The connection term has a negative and noteworthy coefficient just amid the GFC time frame. Drawing from the discoveries of Kearns and Patel (2016) on the relationship among the dimension of outside obligation, development of trade rates, exchange volume, and the job of the 
Table 5. Imports composition effects

\begin{tabular}{lcccc} 
& \multicolumn{4}{c}{ Dynamic gravity model } \\
\cline { 2 - 5 } & Full & & & \\
& period & Pre-GFC & GFC & Post-GFC \\
\hline Log of Primary to processed imports ratio & $-0.0129^{\star *}$ & -0.00818 & -0.000937 & -0.00975 \\
& $(0.00547)$ & $(0.0109)$ & $(0.00796)$ & $(0.0107)$ \\
Log of bilateral RER & $0.388^{\star * *}$ & 0.775 & $1.035^{\star * *}$ & $-0.510^{* *}$ \\
& $(0.0703)$ & $(0.557)$ & $(0.172)$ & $(0.212)$ \\
Log of primary to processed imports ratio $\times$ Log of bilateral RER & -0.00185 & $-0.00431^{*}$ & $-0.00488^{\star *}$ & 0.00261 \\
& $(0.00162)$ & $(0.00249)$ & $(0.00208)$ & $(0.00341)$ \\
Log of Primary to processed imports ratio & $-0.0114^{* *}$ & -0.0100 & 0.000398 & -0.00864 \\
Log of 1 period lag bilateral RER & $(0.00541)$ & $(0.0109)$ & $(0.00792)$ & $(0.0105)$ \\
& $0.430^{\star \star *}$ & 0.621 & $0.124^{* *}$ & $-0.649^{* *}$ \\
Log of primary to processed imports ratio $\times$ Log of 1 period lag & $(0.0702)$ & $(0.434)$ & $(0.0527)$ & $(0.320)$ \\
bilateral RER & -0.00228 & -0.00379 & $-0.00525^{* * *}$ & 0.00220 \\
& & & & \\
& $(0.00158)$ & $(0.00247)$ & $(0.00203)$ & $(0.00333)$ \\
\hline
\end{tabular}

Note: $\mathrm{p}<0: 10 ; \quad \mathrm{p}<0: 05 ; \quad \mathrm{p}<0: 01$ Robust standard errors are in parentheses.

GFC in changing the elements among these factors, this paper endeavors to discover more proof on the inferred basic changes on this relationship pre-and post-GFC.

As Table 7 appears, the normal transient outer obligation of exporters in our example expanded from $3.66 \%$ of GDP pre-GFC to $4.62 \%$ post-GFC, while unexpectedly, the normal momentary outside obligation of shippers in our example declined post-GFC. Note that the dimensions of transient outside obligation as offer of GDP of the two exporters and shippers have not come back to their pre-GFC levels. This focuses to the likelihood that the effect of the emergency on outer obligation may not be impermanent or repetitive, or it ought to have disseminated after some time. This gives inspiration to see momentary outer obligation as one of the basic elements which can clarify the debilitating connection between conversion standard and exchange.

\subsection{Importer's Short-Term External Debt}

In the interim, the shipper's momentary outside obligation, lndebtjt, is found to have a positive effect on fares volume for the pre-GFC and GFC periods (Table 8, Panel B).

Table 8. Short-term external debt stocks effects

\begin{tabular}{llllr} 
& \multicolumn{3}{c}{ Dynamic gravity model } \\
\cline { 2 - 5 } & \multicolumn{1}{c}{ Full period } & Pre-GFC & GFC & Post-GFC \\
\hline A. Exporter's short-term external debt & & & & \\
Log of exporter's short-term external debt & -0.00767 & 0.0462 & 0.0434 & $-0.162^{*}$ \\
& $(0.0190)$ & $(0.0604)$ & $(0.0320)$ & $(0.0927)$ \\
& $0.450^{* * *}$ & 0.503 & $1.774^{* * *}$ & 0.482 \\
Log of bilateral RER & $(0.138)$ & $(0.368)$ & $(0.289)$ & $(0.361)$ \\
& $0.00777^{*}$ & -0.000683 & $-0.0112^{* *}$ & $-0.0379^{* * *}$ \\
Log of exporter's short-term external debt x Log of bilateral RER & $(0.00440)$ & $(0.00818)$ & $(0.00539)$ & $(0.0114)$ \\
& -0.000550 & 0.0240 & $0.130^{* *}$ & -0.111 \\
Log of exporter's short-term external debt & $(0.0215)$ & $(0.0629)$ & $(0.0628)$ & $(0.0937)$ \\
& 0.208 & -0.0105 & $1.189^{* * *}$ & -0.158 \\
Log of 1 period lag bilateral RER & $(0.137)$ & $(0.302)$ & $(0.280)$ & $(0.516)$ \\
& & & & \\
& & & & \\
Log of exporter's short-term external debt x Log of 1 period lag & 0.00631 & 0.000974 & $-0.0121^{* *}$ & $-0.0331^{* * *}$ \\
bilateral RER & $(0.00443)$ & $(0.00884)$ & $(0.00569)$ & $(0.0113)$ \\
& & & & \\
B. Importer's short-term external debt & -0.00292 & $0.114^{* *}$ & $0.0450^{*}$ & 0.124 \\
Log of importer's short-term external debt & $(0.0145)$ & $(0.0492)$ & $(0.0241)$ & $(0.106)$ \\
& $0.521^{* * *}$ & $0.986^{* * *}$ & 0.395 & 0.229 \\
Log of bilateral RER & $(0.107)$ & $(0.332)$ & $(0.262)$ & $(0.316)$ \\
& $-0.00806^{* *}$ & 0.00141 & 0.00464 & -0.00818 \\
Log of importer's short-term external debt x Log of bilateral RER & $(0.00324)$ & $(0.00745)$ & $(0.00603)$ & $(0.0114)$ \\
& -0.0208 & $0.0811^{*}$ & 0.0668 & 0.138 \\
Log of importer's short-term external debt & $(0.0175)$ & $(0.0424)$ & $(0.0648)$ & $(0.106)$ \\
& 0.0353 & $0.863^{* * *}$ & -0.0738 & 0.329 \\
Log of 1 period lag bilateral RER & $(0.0671)$ & $(0.282)$ & $(0.256)$ & $(0.376)$ \\
& & & &
\end{tabular}


Note: $\mathrm{p}<0: 10 ; \quad \mathrm{p}<0: 05 ; \quad \mathrm{p}<0: 01$ Robust standard errors are in parentheses.

Table 6. Imports composition ratio: primary to processed imports volume ratio

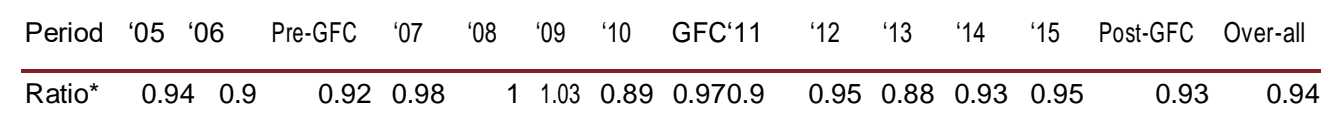

Note: *This pertains to interquartile range value. Source: UN Commodity Trade Database.

Table 7. Average short-term external debt (\% of GDP)

\begin{tabular}{lcc} 
& Exporters & Importers \\
\hline Pre-GFC & 3.66 & 6.76 \\
GF-C & 4.48 & 4.83 \\
Post-GiFC & 4.62 & 4.16 \\
2001-2015 & 4.16 & 5.14 \\
\hline
\end{tabular}

Source: World Bank. World Development Indicators.

\section{Discussion}

A $1 \%$ expansion in the momentary outside obligation supply of merchant prompts a 0.11 and $0.045 \%$ expansion in imports in the pre-GFC and GFC periods, individually. Be that as it may, this effect to a great extent scatters post-GFC. Meanwhile, the coefficient of the connection term among lndebtjt and lnRERijt indicates noteworthy negative outcome in the full time frame estimation. Devaluation of the exporter's cash has less effect on fares amid this period when merchants had high transient outer obligation. This is presumably in light of the fact that bigger transient outside obligation estimation of shipper is mostly counteracted by the deterioration of the exporter nation money. (Note that deterioration of the exporter nation money infers apprecia-tion of merchant nation cash.) Kearns and Patel (2016) has comparative discoveries, with the end goal that the outside obligation could offset the effect on exchange of conversion scale developments. By and large, the exporter's momentary outer obligation level fashions an altogether negative effect on exchange execution post-GFC, while shipper's transient outside obligation level, which expanded exchange pre-GFC and GFC, does not appear to support exchange post-GFC any longer. The two components ought to have added to lukewarm exchange development post-GFC. In the interim, the shipper's transient outer obligation level does not appear to prompt a comparable hosing effect on the conversion standard effect channel post-GFC any longer. As talked about before, the normal momentary outside obligation of exporters (Table 7) in our example expanded which ought to have added to slower exchange development post-GFC as the critical negative coefficient of exporter's transient outer obligation in the estimation demonstrates. Despite what might be expected, the normal momentary outside obligation of merchants in our example declined post-GFC, which could have prompted an intensifying effect of conversion scale on exchange in the event that it had happened pre-GFC, however this effect in actuality has generally disseminated after some time, as talked about above. 


\section{Conclusion}

This paper investigated the effect of the genuine swapping scale level on the fares volume of 72 economies from 2001 to 2015 utilizing gravity model estimation. The after effects of the experimental examination add to the writing by first affirming the debilitated effect of conversion scale on fares volume post-GFC and, second, exploring basic factors as potential channels of this relationship. There is proof of a positive effect of genuine trade rates on fares volume, with the end goal that devaluation of the exporter's money results in higher fares volume. Nonetheless, the effect has essentially debilitated over the long haul, specifically after the GFC. The effect of cash devaluation on exchange has turned out to be a lot littler post-GFC (2012- 2015) contrasted with pre-GFC (2003- 2006), with the effect going on for an a lot shorter time. Further, the gravity model estimation results bolster the significant job of GVCs for development of global exchange, yet in addition discover proof of the debilitated effect of swapping scale deterioration on fares volume, with the advancement of GVC cooperation around the globe. Other basic components tried in the exact investigation -, for example, import creation (i.e., essential to prepared (or fabricated) imported products proportion and the supply of momentary outside obligation of both merchant and exporter) additionally point to the negative effect of these variables on universal exchange, with certain varieties in magni-tude crosswise over different periods. The outcomes likewise propose that potential auxiliary changes could happen post-GFC, which appeared to have debilitated the effect of these elements on the swapping scale go through on exchange.

\section{References}

Ahmed, S., Appendido, M., \& Ruta, M. (2015a). Global value chains and the exchange rate elasticity of exports. International Monetary Fund Working Paper. 15 (552). International Monetary Fund. Washington, D.C.

Ahmed, S., Appendido, M., \& Ruta, M. (2015b). Depreciation without exports? Global value chains and the exchange rate elasticity of exports. World Bank Policy Research Working Paper. 7390, World Bank, Washington, D.C.

Anderson, J. E., \& van Wincoop, E. (2003). Gravity with gravitas: A solution to the border puzzle. American Economic Review, 93, 170-192.

Appuhamilage, A., \& Senanayake, K. (2010). Exchange rate movements' effect on Sri Lanka-China trade. Journal of Chinese Economy and Foreign Trade Studies, 3(3), 254267.

Aristotelous, K. (2001). Exchange-rate volatility, exchange-rate regime, and trade volume:

Evidence from the UK-US export function (1989-1999). Economic Letter, 72, 87-89.

Asian Development Bank (2016). Asian economic integration report 2016. ADB. Manila, Philippines.

Bacchetta, P., \& van Wincoop, E. (2000). Does exchange-rate stability increase trade and welfare? The American Economic Review, 90(5).

Baek, J. (2012). Exchange rate sensitivity of Korea-US bilateral trade: Evidence from industrial trade data. Journal of Korea Trade, 16, 1-21.

Burstein, A., \& Gopinath, G. (2014). International prices and exchange rates. Handbook of International Economics, 4, 391-451.

Campa, J. M., \& Goldberg, L. S. (2005). Exchange rate pass-through into import prices: A macro or micro phenomenon? NBER Working Paper No. 8934. National Bureau of Economic Research, Cambridge, MA. 
Development of "Deutsch Für Touristmus" Teaching Based On Livejournal Website to Improve Student Competence in Tourism Britain International of Linguistics, Arts and Education, 1(2) 135-141

Dell'Ariccia, G. (1999). Exchange rate fluctuations and trade flows: Evidence from the European Union. IMF Staff Papers, 46(3), 315-334.

Ethier, W. (1973). International trade and the forward exchange market. American Economic Review, 63, 494-503.

Feenstra, R., Gagnon, J., \& Knetter, M. (1996). Market share and exchange rate pass-through in world automobile trade. Journal of International Economics, 40(1-2), 187-207.

Fidrmuc, J. (2009). Gravity models in integrated panels. Journal of Empirical Economy, $37(2), 435-446$.

Franke, G. (1991). Exchange rate volatility and international trading strategy. Journal of International Money and Finance, 10, 292-307.

Gala, P. (2008). Real exchange rate levels and economic development: Theoretical analys is and econometric evidence. Cambridge Journal of Economics, 32(2), 1243-1272.

Hooy, C.-W., Law, S.-H., \& Chan, T.-H. (2015). The impact of the Renminbi real exchange rate on ASEAN disaggregated exports to China. Journal of Economic Modelling, 4, 253-259.

Huchet-Bourdon, M., \& Korinek, J. (2011). To what extent do exchange rates and their volatility affect trade? OECD Trade Policy Papers. 119. Organization for Economic Cooperation and Development, Paris.

International Monetary Fund. (2004). Exchange rate volatility and trade flows Some new evidence. Washington, DC: IMF.

International Monetary Fund (2015b). Exchange rates and trade: A disconnects. IMF Working Paper No. 2017-58. IMF. Washington, D.C.

Janice Janice, \& Nagian Toni. (2020). The Effect of Net Profit Margin, Debt to Equity Ratio, and Return on Equity against Company Value in Food and Beverage Manufacturing Sub-sector Companies listed on the Indonesia Stock Exchange, Budapest International Research and Critics Institute 2(1) 522-530

Kearns, J., \& Patel, N. (2016). Does the financial channel of exchange rate offset the trade channel? Bank of International Settlements Quarterly Review. Bank for International Settlements, Basel, Switzerland.

Koren, M., \& Szeidl, A. (2003). Exchange Rate Uncertainty and Export Prices, mimeo. Harvard University.

Krugman, P. (1989). The case for stabilizing exchange rates. Oxford Review of Economic Policy, Oxford University Press. 5(3), 61-72.

Li Bing-quan, et.al. (2020). Analysis on Behavior Factors of Successful Entrepreneurship of College Students of Local University in Guangdong Province,): Britain International of Humanities and Social Sciences 2(1) 34-44.

Teresa Paulina et.al. (2020). the Effect of Accounting Information and Organizational Culture on Decision Making, Budapest International Research and Critics Institute 2(1) 522530. 